\title{
A Critical Comparison between the Classical Divorce Types of Hanbalī and Ja'farī Schools
}

\author{
Klasik Hanbeli ve Caferi Mezheplerinde Uygulanan Boşanma Türlerinin Karşılaştırmalı \\ Analizi
}

Sümeyra Yakar ${ }^{*}$ (D)

\author{
Emine Enise Yakar ${ }^{* *}$
}

\begin{abstract}
Islamic law seeks the harmonious continuation of families and family structure, setting out detailed principles of family life in the main sources of sharīa, the Qur'an and Sunna. That said, the termination of marriage is considered an acceptable solution by Islamic jurists, if the spouses do not fulfil their obligations toward each other due to inharmonious relationship or existing dissention and where there is no hope of reconciliation. This paper seeks to compare the types of divorce within the Hanbalī and Ja'farī schools in order to shed light on the classical period divorce practices and the methodologies of these two schools. Successful divorces are categorised into wājib, mubāh, makrūh, or haram according to their legal validity. In addition to this, divorce practices are also divided into four main types which extend from their implementation and procedural methods; țalāq, khul', țāliq or tafwī̄, and tafrīq. The research aims to compare the unilateral divorce right of the man (țalāq), woman-initiated divorce (khul'), conditional divorce (țāliq or tafwīd ) and judicial termination (tafrī ) by focusing on the opinions of authoritative Hanbalī and Ja'farī scholars. Applying textual comparative methodology and legal perceptual analysis, the study aims to uncover the existent connection between Islamic legal methodologies and different schools when the scholars address any problems and issues related to divorce practice. Although both schools use different methodologies and sources, the similarity of rulings prevail over the differences due to the fact that the marital issues concerning divorce are mainly solved with the main sources (as/ī) rather than secondary sources $(f e r i)$. This comparative research, therefore, aims to shed lights on the similarities between these schools and to clarify the differences regarding the interpretation of legal sources. At the same time, the paper seeks to identify the convergences and divergences between the divorce practices of the two schools. Comparative analysis of divorce types in Ḥanbalī and Ja'farī schools intents to offer a broad perspective to explore the contemporary divorce practices in Muslim countries whose citizens are the followers of these schools. Instead of making a general comparison between the Sunnī and Shi'ī traditions, the research aims to compare the classical Hanbali school which forms the basis of family law in contemporary Saudi jurisprudence with the classical Ja'fari school which forms the basis of family law in the contemporary Iranian jurisprudence. This comparison brings out the influence of the classical schools upon the modern jurisprudences of Saudi Arabia and Iran.
\end{abstract}

\section{Keywords}

Islamic law, Ḥanbalī school, Ja'farī school, divorce (țalāq), woman initiated divorce (khul')

\section{Öz}

İslam hukuku evlilikle başlayan aile birliğinin kurulmasına ve bu birlikteliğin sürekliliğine önem vererek temel fikıh kaynakları olan Kur’an ve Sünnette ayrıntılı hükümler ortaya koymuştur. Eşler arasında çözülemeyecek derecede ortaya

* Corresponding Author: Sümeyra Yakar (Dr.), Iğdır University, Faculty of Theology, Department of Basic Islamic Sciences, Iğdır, Turkey. E-mail: sumeyrayakar@hotmail.com ORCID: 0000-0001-8335-6819

** Emine Enise Yakar (Dr.), Recep Tayyip Erdoğan University, Faculty of Theology, Department of Basic Islamic Sciences, Rize, Turkey. E-mail: emineenise.yakar@erdogan.edu.tr ORCID: 0000-0002-4100-9234

To cite this article: Sumeyra Yakar, Emine Enise Yakar, "A Critical Comparison between the Classical Divorce Types of Hanbalī and Ja'farī Schools." darulfunun ilahiyat 31, 2 (2020): 275-298. https://doi.org/10.26650/di.2020.31.2.803260 
çıkan anlaşmazlık ve problemlere bağlı olarak, makul, meşru ve zorunlu durumlarda talak olarak bilinen boşanma şeri bir çözüm yöntemi olarak kabul edilir. Bu çalışma Hanbeli ve Caferi mezheplerinde klasik dönem alim ve fakihlerinin kabul ederek uyguladığı boşanma türlerini uygulamadaki benzerlik ve farklılıkları ön plana çıkararak karşılaştırmalı olarak incelemektedir. Boşanma hukuki geçerliliği bakımından vacip, mubah, mekruh, haram gibi tasniflere tabi tutulmakla birlikte, uygulanış şekli bakımından talak, hul', taliq/tefwiz ve tefrik/fesh olarak ayrıma tabi tutulmaktadır. Çalışma, erkeğin boşanma hakkı olan talak, kadının boşanma hakkı olan hul', evlilik sözleşmesindeki şartlara bağı olarak gerçekleşen boşanma hakkı olan taliq/tefwiz, ve eşlerden birinin mahkemeye başvurması ile hakim tarafindan mahkemede gerçekleştirilen boşanma hakkı olan tefrik/fesh boşanmalarını, alanında otorite olarak kabul edilen Hanbeli ve Caferi alimlerin görüşlerini baz alarak uygulama bakımından mukayese etmiştir. Metinsel karşılaştırma metodolojisi ve fikhi analiz yöntemini kullanan bu çalışma fikıh alimlerinin boşanma hükümleriyle ilgili problemlerin çözümünde başvurdukları İslam hukuk metodolojileri ve farklı mezhepler arasındaki mevcut bağlantıyı ortaya çıkarmaktadır. Çalışma, Hanbeli ve Caferi mezheplerinin klasik görüşlerine göre, boşanma uygulamaları hakkındaki benzerlik ve farklılıkları açıklamaktadır. Mezhepler arasında metodoloji ve kaynak kullanımı bakımından farklııklar olsa bile, aile hukuku özellikle de boşanma ile ilgili fikhi konularda çözümler fer'i delillerden ziyade fikhın asli delillerinden (Kur’an ve sünnet) alındığı için, bu iki mezhepteki boşanma uygulamalarında ayrıntılarla ilgili konularda farklılıklar olmasına rağmen benzerlikler daha fazladır. Bu karşılaştırmalı çalışma, farklı olan bu fikıh mezhepleri arasındaki benzerlikleri göstermekte ve kaynakların yorumlanmasına bağı olan uygulamadaki farklılıkları netleştirmektedir. Aynı zamanda bu çalışma, klasik dönem Hanbeli ve Caferi mezheplerinde uygulanan boşanma türlerinin karşılaştırmalı analizi, günümüzde bu mezheplerin yaygın olduğu ülkelerdeki aile hukuku ile ilgili hüküm ve uygulamaların anlaşılması için ayrıntılı bir bakış açısı sunmakta ve bu ülkelerdeki boşanma uygulamalarının temelini açıklamaktadır. Bu anlamda, Sunni ve Şii mezhepleri arasında bir karşılaştırma yapmaktan ziyade, Suudi Arabistan devletindeki aile hukukunun temelini oluşturan Hanbeli mezhebi ile İran devletindeki aile hukukunun temelini oluşturan Caferi mezhebinin karşılaştırılması amaçlanmıştır. Bu yönüyle çalışma, klasik İslam hukuku uygulamalarının, modern dönemdeki Suudi Arabistan ve İran hukuk sistemleri ve sistemde kabul gören içtihatlar üzerindeki etkisini ortaya çıkarır.

\section{Anahtar Kelimeler}

İslam hukuku, Hanbeli mezhebi, Caferi mezhebi, Boşanma, Talak, Hul' 


\section{Introduction}

The contemporary legal systems of Saudi Arabia and Iran have both succeeded in generating an enforceable and applicable jurisdiction from the accumulation of classical Hianbalī and Ja 'farī sources respectively. The official judges ( $q \bar{a} d \bar{l} \overline{\mathrm{s}}$ ) in Saudi Arabia overtly deduce their court decisions ( $h u k m s)$ from the classical Hanbalī texts and apply the Hanbalī school methodology in their jurisprudential process. ${ }^{1}$ Although the modern Saudi scholars' interpretation of textual sources discernibly differs from the classical approaches of Hanbali scholars (that is the influence of common Wahhabī understanding which priorities the literal meaning), the verdicts of classical Hanbalī scholars are mainly followed for the contemporary jurisprudential cases concerning familial issues like marriage, divorce, custody and inheritance. ${ }^{2} \mathrm{Al}$-Atawneh claims that the works and opinions of Ibn Qudāma (d. 620/1223), Ibn Taymiyya (d. 728/1328), Ibn Qayyim (d. 751/1350), Mūsā al-Ḥujjāwī (d. 968/1560), al-Futūḥ̄ (d. 971/1564), and Manșūr al-Bahūtī (d. 1051/1641) have privileged status in the jurisprudence amongst them. ${ }^{3}$ In a similar manner with the Saudi legal system, the current Iranian jurisprudence traces back to the classical Ja'farī sources. Article 12 of the Iranian Constitution underscores this priority and states:

"The official religion of Iran is Islam and the Twelve Ja 'farī school [in ușūl al-dīn and al-
fiqh], and this principle will remain eternally immutable. Other Islamic schools, including the
Hanafì, Shāfî̀, Mālikī, Hanbalī, and Zaydī are to be accorded full respect, and their followers
are free to act in accordance with their own jurisprudence in performing their religious rights."”

Although the Iranian jurisprudence implements codified rulings, the regulations of Civil Code concerning social relations ( $m u$ 'àmalāt) are mainly derived from the compilations of the authoritative Ja'farī scholars such as Kuleynī (d. 329/941), Ibn Babaweyh (d. 381/991), Shekh Mufīd (d. 413/1022), al-Tūṣī (d. 460/1067), al-Ḥillī

1 Mumahhad Al-Atawneh, Wahhābì Islam Facing the Challenges of Modernity (Leiden, Boston: Brill, 2010), xvii, 71, 76.

2 Frank E. Vogel, Islamic Law and the Legal System Studies of Saudi Arabia (Leiden, Boston, Köln: Brill, 2000), 84, 120; Sumeyra Yakar, "The Usage of Custom in the Contemporary Legal System of Saudi Arabia: Divorce on Trial," Kilis 7 Aralık Üniversitesi Ilahiyat Fakültesi 6, no. 11 (2019), 379, 385. The official religious institution of Saudi Arabia, the Dār al-Iftā', mainly uses Hanbalī sources in its fatwās. See, Emine Enise Yakar, "The Influential Role of the Practice of Ifta ' in Saudi Politico-Legal Arena," Manchester Journal of Transnational Islamic Law and Practice 16, no. 1 (2020), 35-44.

3 Al-Atawneh, Wahhābī Islam, 76.

4 "The Constitution of the Islamic Republic of Iran," National Legislative Body, 24 October 1979, accessed 20 November, 2020, https://www.refworld.org/cgi-bin/texis/vtx/ rwmain?page $=$ search \&docid=3ae6b56710\&skip=0\&query=constitution\%20\& coi $=$ IRN. 
(d. 676/1277), al-Awwal (d. 786/1384) and al-Thānī (d. 965/1558). ${ }^{5}$ The origins of contemporary legal regulations regarding familial issues in both countries are directly connected with the classical Hanbalī and Ja 'farī schools. The comparison between the classical divorce types of Hanbali and Ja farī jurisprudence intends to shed light on today's divorce practices in these countries which apply Islamic law in their jurisprudential area. The selection criteria of these schools, therefore, are linked to their official application in the modern world instead of making a general comparison between the Sunnī and Shī' $i$ traditions. The opinions of classical scholars whose influence are remarkably noticeable in the modern Saudi and Iranian jurisprudences are given privileged status throughout the paper in order to make the reader to realise the origins of contemporary divorce practices.

In handling divorce applications, the judges ensure that the procedure complies with shar 'i requirements set out in the Qur'an and Sunna and that the process does not reflect the pleasure of the husband in accordance with both schools. Although each type of divorce is permitted in the Islamic legal system, it is not considered recommended by the legal scholars ('ulamā) who frequently cite a narration of the Prophet Muhammad (hadìth) in justification ("The most hated of permissible things to Allah is divorce"). ${ }^{6}$ A Qur'anic verse provides further clarification: "If you fear dissension between the two, send an arbitrator from his people and an arbitrator from her people. If they both desire reconciliation, God will cause it between them." In circumstances in which only one side sues for divorce or the court finds reasonable grounds for reconciliation between the parties, judges prefer to, in seeking to uphold the interests of the marriage, refer the case to the conciliation committee consisting of two arbitrators from both sides. If the conciliation committee manages to reconcile the spouses, the marriage continues; however, if the conciliation committee is reluctant to sanction reconciliation, the authorities confirm the divorce. It is considered more appropriate for arbitrators to have a family bond; however, there is no requirement for arbitrators to possess lineal consanguinity as decision-making skills and a knowledge of the special circumstances are deemed to be sufficient. ${ }^{8}$ The classical approach, in accordance with both schools, adopts an idea that the arbitrators only possess the role of proxy

5 "The Civil Code of the Islamic Republic of Iran," National Legislative Body, 23 May 1928, accessed 20 November, 2020, https://www.refworld.org/docid/49997adb27.html.

6 Muhammad ibn Yazeed ibn Mājah al-Qazwin̄i, Sunan Ibn Mājah, trans. Nasiruddin al-Khattab (Riyadh: Darussalam, 2007), "Kitāb al-Ṭalāq," vol. 3, hadīth no: 2018.

7 English Translation of the Message of the Qur'an, trans. Syed Vickar Ahamed (Illinois: Books of Signs Foundation, 2007), al-Nīsā' 4/35.

8 'Abdullah ibn Ahmad ibn Muhammad Ibn Qudāma al-Maqdisī, Al-Kāfĩ fì Fiqh Ahmad Ibn Hanbal (Dār al-Kutub al-'Ilmiyya, 1994), vol. 3, 94. 
and therefore do not have the right to authorise separation, which is considered the irreversible and undetachable right of the husband. ${ }^{9}$

Within the Hanbalī school, Ibn Qudāma (d. 620/1223), whose contributions have strongly structured the issues regarding divorce, categorises divorce into five which include obligatory (wājib), disapproved (makrūh), permissible (mubāh), recommended (madūb-mustaḥābb) and prohibited (maḩzūr). ${ }^{10}$ Wājib divorce refers to divorce that occurs because of a lack of permission from a guardian or dissention among arbitrators. Makrūh divorce refers to divorce that occurs without any plausible reason and depends upon the principle of no harm and the causing of no harm ( $l \bar{a}$ darar wa-la dir $\bar{a} r$ ). Mubāh divorce is divorce that is undertaken to prevent damage from being inflicted upon one of the parties. Mandūb or mustahāa b divorce refers to divorce that aims to remove the damage upon the wife because of her husbands' hatred or undesirable behaviour. Additionally, if one of the parties does not pay attention to his/her religious duties including the five daily prayers (salāt), fasting (sawm), or ablution (ghusl), the divorce is considered recommendable. ${ }^{11}$ Mahzūr divorce refers to divorce that is pronounced during the menstruation period or after having intercourse with the wife during her purity period. ${ }^{12}$

The authoritative Ja'farī scholars, al-Shahīd al-Awwal (d. 786/1384) and alShahīd al-Thānī (d. 965/1558) classify divorce into four main categories which include obligatory (wājib), recommended (madūb-sunna), disapproved (makrūh), and forbidden (harām). ${ }^{13}$ Wajjib divorce refers to divorce that occurs after the impossibility of reconciliation or after the completion of the 'idda period either through $\bar{i} l \bar{a}$ ' (vow of not having intercourse with the wife) or zihār (comparing one's wife to his mother's back to deem their sexual relationship unlawful). Mandūb or sunna divorce occurs when the spouses do not fulfil their obligations towards each other due to inharmonious relationship and there is no hope of reconciliation. Alternatively, 'idda divorce (completion of three divorce rights after having intercourse at the end of each courses), the irrevocable ( $\left.b \bar{a}^{\prime} i n\right)$ and the revocable (rāji ) divorce types are evaluated under the heading of sunna divorces. ${ }^{14}$ Makrūh

9 Ibn Qudāma, Al-Käfì vol. 3, 47; Al-Ṭūsī, A Concise, 238.

10 Ibn Qudāma, Al-Käfì vol. 3, 106-107.

11 Ibn Qudāma, Al-Käfì, vol. 3, 106.

12 Ibn Qudāma, Al-Käfì, vol. 3, 107.

13 Al-Shahīd al-Awwal (Muhammad ibn Jamāl al-Dīn al-'Āmilī), Al-Lum 'a al-Dimashqiyya (Qom: Dār al-Fiqr, 1994), 180; Al-Shahīd al-Thānī (Zayn al-Dīn 'Ali ibn Aḥmad al-‘Āmilī), Al-Rawda al-Bahiyya Sharh al-Lum 'a al-Dimashqiyya (Qom: Al-Mu’esse al-Ismā‘iliyya, 1999), vol. 2 , 383,384 .

14 Al-Awwal, Al-Lum 'a, 180; Al-Thānī, Sharh al-Lum 'a, vol. 2, 384, 
divorce means to divorce the wife without any reason during harmonious relations. Harām divorce means to divorce the wife without plausible reason in her absence. Despite the fact that these categorisations within both Hanbalī and Ja 'farī schools are established in accordance with the legal validity of divorce, there is also another divorce categorisation that originates in its implementation procedure. These include the unilateral divorce right of the man (talāq), woman-initiated divorce ( $k h u l$ ), conditional divorce (țăliq or tafwì faskh). The practice of temporary marriage ( $m u t^{\prime} a$ ) and divorce rulings concerning this marriage are not evaluated in the paper since its validity is a matter of debate between the schools. ${ }^{15}$ The practice of these types and their regulations in accordance with classical Hanbalī and Ja 'farī schools will be examined in order to engage the question of to what extent they are similar or different from each other. The paper compares the divorce types within the Hanbalī and Ja 'farī schools to shed light on the divorce practices of classical period and methodologies of these schools. The comparative conclusion intends to clarify that the similarities of rulings during the implementation procedure prevail over the differences concerning divorce issues in the two schools despite their application to different methodologies. Although there are notional disparities related to the interpretative methods which are espoused within the Hanbalī and Ja'farī schools, the original source-texts for the divorce rulings (the Qur'an and Sunna) result in a degree of discrepancy minimizing in practical implementation procedure.

\section{Talāq}

In classical shar 'i practice, țalāq corresponds to three unilateral divorce rights or repudiations that the husband can pronounce against the wife, regardless of context or time and in the absence of legal proceedings. ${ }^{16}$ The majority of Hanbali scholars commonly accept a talāq pronunciation during one session as being one use of divorce right with Ibn Hanbal's (d. 241/855) narrations often being cited as justification. That states:

"Abū Dāwud said: I heard Ahmad asked about a man who divorces his wife triply in one statement, and he did not consider that appropriate" [;] "I heard Ahmad asked about a man who says to his wife, 'you are divorced,' meaning triply. Ahmad said, 'it counts as a single divorce."17

15 Sumeyra Yakar, "The Consideration of Bid 'a Concept according to Saudi and Iranian Scholars," Mazahib Jurnal Pemikiran Hukum Islam 19, no. 2 (2020), 235-236, https://doi.org/10.21093/ mj.v19i2.2645.

16 H. İbrahim Acar, “Talāk," Türkiye Diyanet Vakfi Íslam Ansiklopedisi (Ankara: TDV Yayınları, 2010), vol. 39, 496-497.

17 Susan A. Spectorsky, Chapters on Marriage and Divorce Responses of Ibn Hanbal and Ibn Rahwayh (Austin: University of Texas Press, 1993), 69. 
Although there continues to be considerable disagreement among Hanbali scholars on the issue of triple tala $q$ pronouncement and the husband's intention, the majority of scholars align themselves with Ibn Hanbal and Ibn Taymiyya's approach which is the preferable opinion in todays' Saudi legal system. Ibn Taymiyya (d. 728/1328) maintains that one talāq pronouncement should, in the interest of the parties, be conceived as a single, revocable divorce right. ${ }^{18}$

The Ja'farī scholars claim that the formula of divorce should be pronounced in a special and definite way in the presence of two witnesses during the wife's period of purity. The requirement of having at least two witnesses is the main difference of the Ja' fari school in comparison to the Hanbalīs. Al-Awwal states that repudiation does not take effect in the absence of at least two faithful, righteous, and trustworthy witnesses; furthermore, it only has shar ${ }^{\prime} \bar{\imath}$ effect in Arabic. ${ }^{19}$ However, al-Thān̄̄ claims that Arabic language expression is not a required condition of validity in instances of non-Arabic-speaking parties, as long as there is an intention or sense of withdrawal - rather, the formula must be completed by explicitly specifying the subject and object either in an Arabic or their mothertongue. ${ }^{20}$ The husband should pronounce the wording of divorce ("the so-and-so [name of the person or my wife] lady is divorced").

The physical and mental capability of the husband upon uttering the divorce formula is taken into account by the classical Hanbali scholars. Particular modifications of the divorce formula or restorations of the marriage are then undertaken in accordance with the husband's condition. A well-known Hāanbalī scholars, Ibn Qudāma and Ibn Qayyim claim that the pronouncement of talāq when being in a state of immaturity, intoxification, lunacy, madness, sickness or sleep ultimately nullifies it. ${ }^{21}$ This regulation is attained through the analogy to the narration that states: "The pen (qalam) has been lifted from three: from the sleeping person until he awakens, from the minor until he grows up, and from the insane

18 Ahmad ibn 'Abd al-Halīm Ibn Taymiyya, Majmu' al-Fatāwā (Dār al-Wafā', 2005), vol. 33, 46-47; Șālih ibn 'Abd al-'Azīz al-Manșūr, Ușūl al-Fiqh wa Ibn Taymiyya (Egypt: Dar al-Nașr, 1985), 520; Tarek Elgawhary, Rewriting Islamic Law; The Opinions of the 'Ulamā' Towards Codificatoin of Personal Status Law in Egypt (New Jersey: Gorgias Press, 2019), 109-111.

19 Al-Awwal, Al-Lum 'a, 179; Al-Thānī, Sharh al-Lum 'a, vol. 2, 378; Al-Hillī al-Hasan ibn Yūsuf ibn al-Mutahhār, Mukhtalaf al-Shī'a fì Ahkām al-Sharī'a (Qom: I’timād, 2000), vol. 4, 60, 64.

20 Al-Awwal, Al-Lum 'a, 179; Al-Thān̄̄, Sharh al-Lum 'a, vol. 2, 378, 379; Al-Hiillī, Mukhtalaf al-Shī'a, vol. 4, 60.

21 Ibn Qudāma, Al-Kāfì, vol. 3, 110; Muhammad ibn Abī Bakr ibn Ayyūb Ibn Qayyim al-Jawziyya, Iqhāthat al-Lahfān fì Hukm Ṭalāq al-Ghaụbān (Jeddah: Majmu'u al-Fiqh al-Islāmī), 3-8. 
until he comes back to his senses." ${ }^{22}$ The word for the divorce formula may be explicit (sarīh) or implicit (kināya) for both țalāq as well as khul . The pronunciation of the explicit divorce formula by the husband, where he is of sound mind and sense, takes effect immediately. In contrast, the implicit utterance of repudiation (such as 'go away', 'God rewards you', 'swallow and taste') is conceptualized and authorized with reference to the code of conduct, customary barriers and intention that apply within a given region. ${ }^{23}$ Ibn Qudāma insists that only the intention of talāq (which operates in the absence of action) does not provide a shar ' $\bar{l}$ ground for divorce; however the explicit pronouncement of talāq even in the absence of intention is considered within the school's established tradition to be valid. ${ }^{24}$ When the implicit divorce formula is uttered in a situation of extreme anger and anxiety, it is not regarded as a valid divorce as there is a clear lack of explicit pronunciation and intent. ${ }^{25} \mathrm{It}$ is also conceivable that the validity of metaphorical expressions for the pronouncement of divorce could be made dependent upon the explicit utterance and intention of the word - however, this applies on the precondition that the word phrasing is customarily known and sufficient for the termination.

The metaphorical or implicit formulas do not result in acceptable divorces from the viewpoint of Ja 'farī scholars because the allusive pronouncement of talāq and its efficacy brings forth vagueness and uncertainty. The formula should be clearly expressed verbally because the written form of repudiation, whether intentional or unintentional, is held to be inadequate and insufficient from the shar ' $i$ perspective, except for the case of a mute husband or an individual with speech impediments. ${ }^{26}$ The explicit character of the divorce formula should be deduced from all customary, legal, and linguistic dimensions of the pronouncement because the uncertainty of usage in any one of these spheres results in the divorce attempt being invalidated. ${ }^{27}$ Al-Ṭusīi (d. 460/1067) observes that the man must clearly indicate an intention to repudiate his wife - for this reason, his subsequent act, interpretation or statement must be consistent with the intention of annulment. ${ }^{28}$ Therefore, the status of

22 The word 'pen (qalam) means liability and obligation. Ibn Mājah, Sunan Ibn Mājah, "Kitāb al-Ṭalāq," vol. 3, hadīth no: 2041.

23 Ibn Qudāma, Al-Kāfí, vol. 3, 97-98, 113-116; 'Amr ibn al-Husayn al-Khiraqī Abū al-Qāsim, Matn al-Khiraqū 'alā Madhhab Abū 'Abdallāh Aḥmad ibn Hanbal Al-Shaybān̄̄ (Medina: Dār al-Ṣahāāba li-Turāth, 1993), 111.

24 Ibn Qudāma, Al-Kāfì , vol. 3, 113-116.

25 Ibn Qudāma, Al-Kāfĭ, vol. 3, 116; Ibn Qayyim al-Jawziyya, Iqhāthat al-Lahfān, 51.

26 Al-Awwal, Al-Lum 'a, 179; Al-Thānī, Sharḥ al-Lum 'a, vol. 2, 379.

27 Abū Ja 'far Muḥammad ibn al-Ḥasan al-Ṭūsī, Kitāb al-Khilāf (Najaf: Al-Nashr al-Islāmī, 1995), vol. 4, 460-461. 
intention (niyya) for the divorce issues in the Ja 'fari school presents a similar manner that is adopted by the Hanbali scholars. The maturity and sanity of the husband are essential requirements to the shar ' $\bar{l}$ validity of divorce, and al-Hilli (d. 726/1325) establishes an age boundary of ten years by refusing to accept the marriage repudiations of those younger than this age. ${ }^{29} \mathrm{~A}$ Ja ${ }^{6}$ farī scholar, al-Ṭusī further states:

"[A] boy of ten years and over who knows very well how to conduct divorce may divorce his wife and his divorce is valid... If he is under ten and does not know how to conduct a divorce, he is not allowed to divorce, and his guardian is not allowed to divorce his wife for him either." ${ }^{30}$

In setting this age restriction for legitimacy, Ja 'farī scholars establish a barrier for shar ' $i$ liability that clearly diverges from Hanbalīs (they restrict the liability with being minor but do not define any age limit). If divorce is illicit (e.g. conducted at an age below this threshold), the marriage contract or the divorce formula loses its validity on the ground of liability. Al-Awwal claims that the repudiation of marriage by the guardian of an insane husband is valid, but the guardian does not have the same right with regard to minor or intoxicated conditions. ${ }^{31}$ In a manner that quite similar with Hanbalī approach, the pronouncement of divorce in a state of anger, coercion or intoxication is considered to be invalid as it indicates a lack of conscience and sense. ${ }^{32}$ The Ja'farī scholar al-Hillī claims that once the marriage is consummated, any divorce attempt in the category of rāji ' (revocable) should satisfy particular conditions which include that the wife should not be a minor or menopausal $\left(y \bar{a}{ }^{\prime} \bar{l} s a\right) .{ }^{33}$ In instances where divorce is irrevocable, the woman is not, presuming that pregnancy is not a consideration, entitled to maintenance or lodging. ${ }^{34}$ With regard to the revocable tala $q$, the husband has the power to revoke his divorce before the expiration of his wife's 'idda period without the need of issuing new marriage contract.

The majority of Ja 'farī scholars concur that the pronunciation of three consecutive talā $q$ formula without any interruption voids the divorce in part of number. On this circumstance, only one divorce takes place and the person protects his two talā $q$ pronunciation rights. Al-Ṭūsī agrees with this condition by observing that

29 Al-Ḥillī, Mukhtalaf al-Shī'a, vol. 4, 49.

30 Abū Ja'far Muhammad ibn al-Ḥasan al-Ṭūsī, A Concise Description of Islamic Law and Legal Opinions, trans. A. Ezzati (London: Icas Press, 2008), 367.

31 Al-Awwal, Al-Lum 'a, 179; Al-Thānī, Sharh al-Lum 'a, vol. 2, 380.

32 Al-Ṭ̄ūsì, Kitāb al-Khilāf, vol. 4, 480; Al-Hiillī, Mukhtalaf al-Shī'a, vol. 4, 50, 51.

33 Al-Hillī̄, Mukhtalaf al-Shī‘ $a$, vol. 4, 62.

34 Syed Ali Raza Naqvi, Shia Divorce Law (Lahore: The Ahl al-Bait, 2012), 286. 
when a man, subject to prescribed conditions, divorces his wife one, two or three times, the divorce will not be counted more than once. ${ }^{35}$ However, if the husband divorces his wife and then revokes his decision during the 'idda period by having intercourse with the wife before then waiting for a period of purity and completing this circulation three times (without intercourse in the final instance), the divorce becomes irrevocable ( 'idda divorce). The first two of the consecutive divorces are considered to be revocable and the final one is maintained to be irrevocable tala $q .{ }^{36}$ If the husband divorces his wife before consummating the marriage, he owes the wife half of the dower that was agreed upon at the start of the marriage. Upon the payment of the whole dower, the husband is entitled to request half of it to be returned.$^{37}$ However, if the parties separate before the consummation of the marriage without a specified dower, the wife may be entitled to a gift payment (mut ' $a$ ) - as al-Ṭūsī observes, its amount should be determined in accordance with the capacity of the husband and local 'urf..$^{38}$

\section{Khul}

The $k h u l$ ' divorce is initiated by the woman and is obtained with the man's consent by her renunciation of any remaining economic rights. This is a repudiation of the wife by the husband in return for obtaining particular amount of payment which is issued upon the basis of the wife's unwilling to persevere with the marriage. ${ }^{39}$ A woman who participates in this type of divorce is known as a mukhtali ' $a{ }^{40}$ The couple agrees upon a divorce settlement by the wife's request. As a result, the husband obtains a right to dissolve the marriage at will without the payment of dower - it is this feature that distinguishes this type of divorce from talāq divorce. Additionally, in the Ja'farī school, the termination of a marriage on the basis of mutual aversion between the spouses is known as mubārāt. The ransom of mubārāt divorce can either be waiving the dower in part or whole or making a payment to the husband that does not exceed the dower amount. ${ }^{41}$ In categorizing mubārāt divorce outside of either tafrī $q$ and $\operatorname{tal} \bar{q} q$ in the Ja'farī school, al-Ṭūsī suggests that the respective parties do not need to apply to a judge to terminate the marriage

35 Al-Ṭūsī, Kitāb al-Khilāf, vol. 4, 450, 451.

36 Al-Hillī, Mukhtalaf al-Shī'a, vol. 4, 67.

37 Al-Ṭūsī, A Concise, 344, 345.

38 Al-Ṭūsī, A Concise, 345.

39 Ibn Qudāma, Al-Kāfì vol. 3, 95, Al-Awwal, Al-Lum 'a, 184, 185.

40 Fahrettin Atar, "Muhālea," Türkiye Diyanet Vakfi İslam Ansiklopedisi (Ankara: TDV Yayınları, 2005), vol. 30, 399.

41 Al-Awwal, Al-Lum 'a, 184, 185; Al-Thānī, Sharh al-Lum 'a, vol. 2, 380. 
unless the dispute relates to custody, maintenance, or residence. ${ }^{42}$ The Hanbalī scholars do not recognise, or practice the mubārāt divorce - if the termination derives from the mutual agreement of both parties, it is categorised under khul or tafrī in the Hanbalī school. The concern that the spouses will not live together as under the permitted limits of sharì' $a$ provides an additional justification. The origin of khul 'divorce traces back to the Qur'an and specifically to the following Qur'anic verse which states:

"...And it is not lawful for you to take anything of what you have given them unless both fear that they will not be able to keep (within) the limits of Allah. But if you fear that they will not keep (within) the limits of Allah then there is no blame upon either of them concerning that by which she ransoms herself. These are the limits of Allah, so do not transgress them." ${ }^{43}$

The practice of khul divorce also finds its root in the hadith sources- Habiba bint Sahl's dislike of Thābit ibn Qays being relevant in this respect. ${ }^{44}$ It is important to recognise that the wife, as the initiator of the divorce in $k h u l$ ', should harbour dislike towards her husband and not vice-versa. The Ḥanbalī scholar, Ibn Qudāma, divides $k h u l$ ' into three categories with each one being distinguished upon the basis of its anticipating reasons and financial results: in the first type, the wife's dislike or abstinence from her husband results in the relinquishing of her financial rights and the return of the dower. In the second type, continuous discord between spouses results in separation being valid but not recommendable, with the wife again renouncing her financial rights. In the third type, an appeal is issued to the court to terminate the marriage upon the grounds that the husband has badly treated the wife. However, in this third case, the financial rights of the wife is preserved, and she is not obligated to return the $m a h r .{ }^{45}$ This type closely resembles the judicial divorce (tafri $q$ ) as the husband's consent for divorce is absent. ${ }^{46}$ The pronunciation of the khul ' divorce outside the court or during menstruation (this would be deemed to be unacceptable for the talāq divorce) is not understood to undermine the validity of the dissolution, as the wife has forsaken her financial rights ${ }^{47}$ Talaq divorce that occurs during the menstruation period is considered to be undesirable and prohibited (maḩūur), but khul' divorce during the menstruation

42 Al-Ṭūsī, Kitāb al-Khilāf, vol. 4, 424.

43 al-Baqara 2/229.

44 Ibn Mājah, Sunan Ibn Mājah, "Kitāb al-Ṭalāq," vol. 3, hadīth no: 2057; Mustafa Karataş, "Sābit b. Kays b. Semmās," Türkiye Diyanet Vakfi İslam Ansiklopedisi (Ankara: TDV Yayınları, 2008), vol. 35, 352; Spectorsky, Chapters, 109.

45 Ibn Qudāma, Al-Käfì vol. 3, 95-96.

46 Yakar, "The Usage of Custom," 373, 379.

47 Ibn Qudāma, Al-Kāfì, vol. 3, 97. 
period does not arouse comparable objections in the Hiannbalī school. ${ }^{48}$ There will not be any maintenance payment during the 'idda period since the woman is the one who initiated the divorce. The Ja 'fari scholars state that the person who pronounces khul ' must satisfy particular conditions - he must therefore be free, mature and possessed of clear intention. The consensus among the majority of classical Ja 'fari scholars establishes that a $\mathrm{khul}^{\prime}$ divorce takes absolute effect through the use of the divorce formula without there being any need to add the word ' $k h u l$ '. ${ }^{49}$ The formula should however be pronounced in the presence of two witnesses and during a period of purification. ${ }^{50}$ These two requirements of Ja farī school demonstrate differences from the Hanbalī school.

The classical Hanbali sources allow the court to adjudicate $k h u l$ ' for an appropriate exchange in the event that the husband is arbitrary or obstinate in his refusal. The majority of Hanbali scholars do not approve the repayment of compensation that exceeds the dower amount - this is justified with reference to the narration of the Prophet Muhammad ("The Prophet ordered Thābit ibn Qays to take from his wife the garden (given as a mahr) without addition.") ${ }^{51}$ Additional justification is provided by Ibn Hanbal's response ("No, I do not like him to do that (la a 'jibunī )" $)^{52}$ to the husband who wished, after a khul 'divorce, to take more back from his wife than he had originally given. In addition, three dirhams $\mathrm{s}^{53}$ is established as the smallest price of her freedom in Hanbalī school. Ibn Qudāma observes that if the

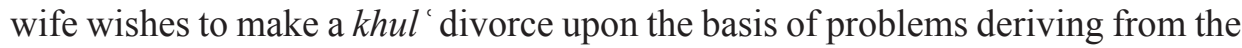
husband, the husband should disclaim the half of the mahr in return for the benefit that he obtained during the marriage. ${ }^{54}$

In the Ja'farī school, issues relating to the dower which include its payment time or quantity must be specified in the marriage contract in order to remove all doubt and uncertainty from disputable cases. In addressing himself to the minimum limit, alThānī observes that it can be as little as a grain of wheat, but it must be accompanied

48 Ibn Qudāma, Al-Kāfì, vol. 3, 107.

49 Al-Thānī, Sharh al-Lum 'a, vol. 3, 2.

50 Al-Thānī, Sharh al-Lum 'a, vol. 3, 3; Al-Ṭūsī, Kitāb al-Khilāf, vol. 4, 422-424.

51 Ibn Mājah, Sunan Ibn Mājah, "Kitāb al-Ṭalāq," vol. 3, hadīth no: 2056; Karataş, "Sābit b. Kays," vol. 35,352 .

52 Spectorsky, Chapters, 80 .

53 Dirham: The Islamic dirham is a specific weight of pure silver equivalent to 3.0 grammes or 2.975 grammes. See M. Zarra Nezhad, "A Brief History of Money in Islam and Estimating the Value of Dirham and Dīnār," International Association for Islamic Economics 8, no. 2 (2014), $52-56$.

54 Ibn Qudāma, Al-Kāfì, vol. 3, 66. 
by the capacity of appreciation and evaluation. In addressing the maximum limit, he notes that there is a consensus of opinion among Ja 'farī scholars that forbids the request of dower in excess of the mahr al-sunna (five hundred dirhams or fifty dinars). ${ }^{55}$ If the dower is qualitative or descriptive (e.g. teaching knowledge) rather than quantitative or definite, local norms and customary criteria are used in order to determine its character. However, an amount in excess of fifty dinars would not be considered to be legitimate dower and it will not therefore be approved. In a manner that closely dissembles from the Hanbali school, the determination of the upper limit for dower makes the Ja 'farī school different. A particular amount (equal, less or more than her dower, depending on the circumstance) should be paid to the husband in order to obtain the wife's release from him (but the amount should not exceed fifty dinars).$^{56} \mathrm{Al}$-Awwal states that the amount, quality and quantity of ransom should be clearly defined and signed, and the ransom should be paid in the local currency if a preferred currency is not indicated..$^{57}$ The husband is not entitled to renounce his decision or return to his 'partner' unless she reclaims her ransom. As being an irrevocable divorce, the wife becomes unlawful to the husband unless there is intermediary shar ' $i$ marriage with another man. However, according to Ja'farī scholar al-Ṭ̂̄sī, if she reclaims her ransom, the divorce is considered to be revocable one and it is considered to be tala $q$ divorce. ${ }^{58}$ She is then entitled to maintenance and residence from the point that the husband becomes aware of the wife's demand. According to Ja'farī school, the process after the khul ' divorce may transform it from irrevocable to revocable - this however depends upon the wife's reclamation of the compensation during her waiting period.

There is no consensus upon whether $k h u l$ ' permits the divorced women to retain compensation during 'idda period. If a man agrees with releasing the wife with $k h u l$ ' divorce, al-Ṭūsī maintains that there would be no 'idda. Al-Hiillī, meanwhile, claims that there should be 'idda as it entails release from a contract. ${ }^{59}$ The narration establishes that a woman who has been granted khul' divorce is not entitled to maintenance nor residence; however, she is required to observe the 'idda in the same way as a normally divorced woman would, for the determination of pregnancy. ${ }^{60} \mathrm{Al}-$ Hillī states that if the annulment is caused by the wife's actions as embodied within

55 Al-Thānī, Sharh al-Lum 'a, vol. 2, 333-335.

56 Al-Thānī, Sharh al-Lum 'a, vol. 3, 4.

57 Al-Awwal, Al-Lum 'a, 184; Al-Ṭūsī, Kitāb al-Khilāf, vol. 4, 434.

58 Al-Ṭūsī, Kitāb al-Khiläf, vol. 4, 426, 429.

59 Naqvi, Shia Divorce, 262.

60 Muhammad ibn Ya'qūb al-Kulayn̄i, Furū' al-Kāfì (Beirut: Manshūrāt al-Fajr, 2007), vol. 6, 92, 93. 
her apostasy, conversion, demand or mistake the woman will be held responsible for the separation and she will not be entitled in the form of a dower, divorce gift (mut ${ }^{\prime} a$ ) or maintenance payment. ${ }^{61}$ However, in establishing that the $k h u l$ ' divorce is revocable for the duration of ' $i d d a$, al-Thāni notes that maintenance and waiting periods are compulsory procedures. This applies to the any wife of child-bearing age, with the exclusion of menopausal, minor and non-consummated examples. ${ }^{62}$ If the husband abuses, beats or compels his wife with the intention of obtaining her

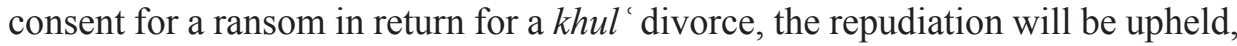
but the payment of ransom will be unlawful. ${ }^{63}$

\section{Ṭalīq or Tafwìd}

The insertion of specific conditions (shurüt) into the marriage contract at the beginning of the marriage enables parties, in particular women, to access divorce without waiving their financial rights and this practice is known as talīq or tafwì divorce. ${ }^{64}$ Upon deciding to marry his daughter to someone with or without her consent, the guardian (usually the father or paternal male relatives of the bride) settles the marriage conditions. ${ }^{65}$ In the time that these anticipated events occur, the wife will be able to easily invoke the right of divorce. Stipulations in marriage contracts, according to Hanbali approach, can be broken down into three categories: those which invalidate the whole contract, those which are valid and enforceable, and those which are void but which do not invalidate the contract. ${ }^{66}$ Ibn Hanbal states:

\footnotetext{
"The marriage contract is valid, but the condition is invalid. The contract is legitimate even with obscure conditions because it is not nullified with void conditions in the same vein with 'atī $q$...If there is a stipulation stating that the dower is performed at such a time and there will be no marriage between them until the parties satisfy the condition, the condition is accepted valid because it preserves benefits of the parties. This term resembles in many aspects the condition of not moving the wife from her residential area." ${ }^{67}$
}

61 Naqvi, Shia Divorce, 179.

62 Al-Thānī, Sharh al-Lum 'a, vol. 3, 8.

63 Al-Awwal, Al-Lum 'a, 184; Al-Thānī, Sharh al-Lum 'a, vol. 3, 7.

64 Ziba Mir-Hosseini, "The Delegated Right to Divorce in Iran and Morocco," in Talaq-i-Tafwid: The Muslim Woman's Contractual Access to Divorce, ed. Lucy Carrol and Harsh Kapoor (WLUML, 1996), 121-134.

65 Al-Ṭ̂ūsī, A Concise, 341, 343; Al-Thānī, Sharh al-Lum 'a, vol. 2, 275.

66 Dawoud Sudqi El-Alami and Doreen Hinchcliffe, Islamic Marriage and Divorce Laws of the Arab World (London: CIMEL, 1996), 8.

67 Ibn Qudāma, Al-Kāfì, vol. 3, 42. 
The consensus opinion among Hanbalī scholars holds that the marriage remains in force even if certain invalid conditions (e.g. marrying without dower or relinquishing maintenance) are present - in these instances, it is instead the stipulations that are considered to be invalid and in need of revision. To the same extent with Hanbali approach, inserting a condition that contradicts the doctrines of shari' $a$ nullifies the validity of the stipulation and does not affect the legitimacy of marriage according to Ja'farī school. If there is a stipulation for the husband which states that he should not be responsible for maintenance, the term is considered to be void because the textual sources establish that this is the main responsibility of the husband. ${ }^{68} \mathrm{Al}-\mathrm{T}$ ūsī asserts:

"If a man marries a woman but includes in the marriage contract something contrary to the Qur'an and the tradition set by the Prophet (saas), the marriage is valid, but the contrary conditions are invalid - e.g., terms such as promising not to take another wife [the condition of promising not to marry another woman at the same time is regarded as valid by most contemporary Muslim lawyers], not to marry at all if she dies and similar terms. All these terms are invalid. They may be ignored." ${ }^{69}$

It should be noted that the Hanbali school advocates or allows the widest range of stipulations for the marriage contract, and that these extend to cover polygamy or the wife's relocation..$^{70}$ This is shown by Ibn Hanbal's response to a question relating to the bride's residence ("Then he can never expel her from her house."71) Upon attaining the agreement and consent of the parties, the stipulations obtain validity and sanction power in disputed circumstances. Ibn Qudāma provides a clear explanation about the generality of stipulations. He states:

"The conditions give benefit to the wife such as an increase on the specified mahr price, certain amount of money, not marrying with another woman, hesitating from it, not travelling with him, not moving from the residential location or country. All of them are valid and require obedience to terms. The narration of the Prophet states that: 'The best conditions are the ones that obtains agreement in the marriage time.' There was a man who married a woman with the condition of not leaving from her city. After that the man wanted to move [from his wife's city] and their case was referred to Omar for the decision. He stated that if there was such a condition, the husband was required to obey it. The man applied for divorce and Omar adjudicated that the divorce was valid on account of conditional stipulation. Since the prevailing circumstance [which was to leave from the wife's city] was against the intended purpose [and stipulations] of the marriage, the divorce became legitimate." 72

68 Al-Awwal, Al-Lum 'a, 167; Al-Ṭūsī, A Concise, 346.

69 Al-Ṭūsī, A Concise, 346.

70 Kecia Ali, "Marriage in Classical Islamic Jurisprudence: A Survey of Doctrines," in The Islamic Marriage Contract Case Studies in Islamic Family Law, ed. Asifa Quraishi and Frank E. Vogel (Massachusetts: Harvard University Press, 2008) 21.

71 Spectorsky, Chapters, 69.

72 Ibn Qudāma, Al-Kāfì vol. 3, 39-40. 
This quotation clearly highlights the main approaches that classical Hanbali scholars have adopted towards marriage conditions while also reiterating the scope of the implementation. In a general sense, the Hanbali school allows a wife to dissolve the marriage if the husband agrees to grant her this right at the time of marriage or subsequently. In Ja'farī school, a husband may delegate his power of repudiation to his wife by either restricting it with an extended period of time or conditioning it upon the occurrence of a specified event. An opinion which is compatible with the general principles of $\operatorname{shari}^{-} a$ establishes that the delegation of the power of divorce to the wife is considered to be acceptable when she possesses the necessary qualification of being an agent. ${ }^{73}$ Upon encountering the condition which relates to the woman's demand of the ransom for the khul ' and mubārāt divorces during the 'idda period, the husband becomes eligible to demand her return to marriage, and the stipulation is considered to be lawful and applicable. ${ }^{74}$ The definite conditions entitle both parties to access legitimate divorce without losing the financial rights granted by the lawgiver.

In highlighting the essentiality of righteousness, al-Hilli notes that if the man contracts to marry upon the basis of claimed membership of a tribe that later proves to be false, the woman has the right to cancel the marriage upon the basis of the dishonour and shame that has been inflicted upon her status. ${ }^{75}$ In variation with the shar ' $\bar{l}$ rulings, the false pretence and inaccurate statement issued during the determination of conditions invalidate the contract. The main attribute that differentiates this type of divorce from others is that although the wife is the initiator of the divorce, her financial rights whether dower ( $m a h r$ ), maintenance (nafaqa) or custody (hadāna) are preserved by the contract. It should be observed that the comparison of financial and marriage contracts derives its root from the binding power of the contractual stipulations and their functionality.

\section{Tafrīq or Faskh}

Tafriq or faskh refers to the annulment of a marriage that is obtained through a court decree when either the husband or wife file for divorce by petitioning the authorities to annul the marriage. ${ }^{76}$ As shar $\bar{\imath}$ authorities or judges are mainly responsible for the annulment of marriage, it cannot be said to be equivalent to țalāq, khul', țalīq or tafwīẹ divorces. Classical Hanbalī sources, as the opinions

73 Naqvi, Shia Divorce, 26.

74 Naqvi, Shia Divorce, 484.

75 Naqvi, Shia Marriage, 496.

76 H. İbrahim Acar, "Tafrik," Türkiye Diyanet Vakfi İslam Ansiklopedisi (Ankara: TDV Yayınları, 2011), vol. 40, 277-278. 
of Ibn Hanbal, Ibn Qudāma and Ibn Qayyim attest, agree that divorce upon the grounds of a defect ('ayb) within either spouse offers a sufficiently strong shar' $\bar{l}$ grounding for divorce. Ibn Qudāma observes that if health problems, whether upon the part of the husband or wife, prevent the full enjoyment of marriage, there is an option to dissolve the marriage contract. He lists seven health problems that can be categorised as defect depending on textual sources. These are: insanity (junūn), black leprosy (judhdhām), white leprosy (baras) (both parties); removal of the male organ (jubb), impotence ( 'inna) (male party); genital disease (ratq) and hernia (fitiq) (female party). ${ }^{77}$ Ibn Hanbal states that if the wife consents to the marriage without knowing the defects of her husband, she is entitled to petition for divorce; however, this does not apply if she consented to the marriage in full knowledge of the defect. ${ }^{78}$ The judge is then tasked with deciding whether the reason for divorce is justifiable and whether the divorce is considered to be revocable one. ${ }^{79}$ In referring to customary norms for justifying the defection of spouses, Ibn Qayyim enlarges the scope of the defect by providing the widest definition of what causes aversion to the other spouse without listing them definitively. ${ }^{80}$ This applies because the marriage contract is performed upon the basis of the assumption that it is flawless.

In a similar manner with Hanbalī school, Ja'farī scholars state that upon discovering a defect or physical distortion in one party that was unknown prior to the conclusion of the contract, the other party has the right to immediately endorse the case or refer it to the judge for cancellation. The wife can cite the husband's insanity (junūn), eunuch (khișa $\left.\bar{a}^{\prime}\right)$, removal of the male organ (jubb), impotence ( 'inna), and black leprosy (judhdhām); the husband can cite the wife's insanity (junūn), black leprosy (judhdhām), white leprosy (baraș), blindness ( 'amā'), paralysis ( $i q$ ' $\bar{a} d$ ), fleshy protuberance (qarn), fistula (if $d \bar{a}$ '), hernia ('afal) and genital disease $(\mathrm{ratq}) \cdot{ }^{81}$ Any one of these factors provides the other party, subject to the approval of a judge, sufficient grounds for the cancellation of a marriage. ${ }^{82}$ In any case, the controversial nature of dissolution entails that cancellation cannot be put into effect without the presence of the judge in Ja'farī school. However, if the parties are aware of the problem before the accomplishment of the contract,

77 Ibn Qudāma, Al-Kāfì, vol. 3, 42.

78 Ibn Qudāma, Al-Kāfì, vol. 3, 44.

79 Ibn Qudāma, Al-Kāfì, vol. 3, 42-44, 66.

80 Ibn Qayyim al-Jawziyya, Iqhāthat al-Lahfān, 50-59.

81 Abū Ja'far Muhammad ibn al-Ḥasan al-Ṭūsī, Al-Mabsūt fì Fiqh al-Imāmiyya (Beirut: Dār alKitāb al-Islāmī, 1992), 249-250.

82 Al-Awwal, Al-Lum 'a, 172-173; Al-Thānī, Sharh al-Lum 'a, vol. 2, 345-347; Al-Ṭūsī, Al-Mabsūtt, 249-250. 
they no longer provide sufficient grounds for the marriage to be dissolved upon ground of defect. ${ }^{83} \mathrm{Al}$-T ūsi claims that the repudiation could be ordered by the judge on the ground of husband's physical impotency or financial incapability. ${ }^{84}$

In Hanbalī school, the husband's failure to make maintenance payments and lack of property, both of which demonstrate his inability to provide financial support, are deemed to provide shar 'i grounds upon which the wife can request the termination of the marriage. Ibn Qudāma observes that each of the parties are required to complete their duties or responsibilities during the marriage with maintenance being the obligation of the husband. The Qur'anic verse clearly demonstrates: "And due to the wives is similar to what is expected of them, according to what is reasonable. But the men have a degree over them (in responsibility and authority)." ${ }^{95}$ The amount of maintenance is not only defined with reference to local factors but also the social status of the wife and her living conditions. In addition to referring to the failure of the maintenance, Ibn Hanbal also approves the wife's divorce petition upon the grounds that her husband has been imprisoned for a single year or longer without leaving financial support - he achieves this by categorising the case within the framework of the marriage's annulment. ${ }^{86}$

The concept of disobedience (nushüz) in the classical shar ' $\bar{l}$ sources is explained with reference to one spouse's disobedience to the other upon lawful matters which would entail the lapsing of marital rights, along with responsibilities which include cohabitation or maintenance. ${ }^{87} \mathrm{Ibn}$ Qudāma divides $n u s h \bar{u} z$ into two types: the first is the disobedience of the wife - in behaving against the will of her husband and exceeding the shar $i$ borders of the marriage contract. ${ }^{88}$ Both of these acts cause a valid ground for divorce. The consensus within the Hanbali school establishes that the wife, retaining in the status of $n u s h \bar{u} z$, does not only forfeit cohabitation and maintenance - rather the situation also entitles her to educative measurement or particular treatments that will enable her to correct her misconduct. ${ }^{89}$ This is indicated in the following verse: “...But those (wives) from whom you fear arrogance (first) advise them (then if they persist), forsake them in bed, and (finally) strike them.

83 Naqvi, Shia Divorce, 481.

84 Al-Ṭūsī, Kitāb al-Khilāf, vol. 5, 118.

85 al-Baqara $2 / 228$.

86 Jamal J. Nasir, The Status of Women Under Islamic Law and Under Modern Islamic Legislation (London: Graham Trotman, 1990), 93.

87 Hac1 Mehmet Günay, "Nüşūz," Türkiye Diyanet Vakfi İslam Ansiklopedisi (Ankara: TDV Yayınları, 2007), vol. 33, 303.

88 Ibn Qudāma, Al-Kāfì, vol. 3, 92.

89 Ibn Qudāma, Al-Kāfì, vol. 3, 92. 
But if they obey you (once more), seek no means against them." ${ }^{90}$ Ibn Qudāma interprets the concept of punishment (darab) that is outlined within the verse to refer to the rectification of misbehaviour through disciplining her. ${ }^{91}$ If the wife disobeys or rejects a court verdict that orders her to return to the marital home, the classical implementation applies $n u s h \bar{u} z$ and cuts her maintenance payments. The second type of disobedience in Hanbali school is related to the husband's misbehaviour and does not therefore negatively impact the wife's entitlement to maintenance. If the husband abstains from his wife because of her age, illness or related reasons, this is considered to fall within the scope of the husband's nushüz - this applies even if his wife retains her desires. The justification of divorce upon the grounds of disobedience in Hanbalī school is also referred to by a relevant verse: "And if a woman fears from her husbands' contempt or evasion, there is no sin upon them if they make terms of settlement between them, and settlement is best." ${ }^{\prime 92}$ A Hanbali scholar Khiraqi (d. 334/946) states that if there is the possibility that the spouses will reconcile, it is recommended for them to achieve peaceful cohabitation by working through their problems under an arbitrator's guidance. ${ }^{93}$ However, if it is not possible to achieve a settlement, the husband is entitled to obtain divorce through a unilateral pronunciation of talāq or the wife is entitled to apply to a court for a judicial divorce that preserves her entitlement to dower and maintenance.

In Ja'farī school, disobedience or recalcitrance of the wife towards her husband also provides a plausible excuse for the validity of divorce..$^{94}$ If the husband annuls the marriage with revocable pronouncement upon the basis of the wife's nushüz, a clear ambiguity arises in relation to the wife's maintenance and residence rights unless she is able to prove her pregnancy. ${ }^{95}$ The provision of maintenance in accordance with personal circumstances and custom is one of the main responsibilities of the husband within the marriage. The rule even applies in instances of nushüz, as disobedience does not entail any change in the wife's shar 'i status. $^{96}$ As Ṭabātabā' $\overline{1}$ observes that absence of the husband inflicts considerable damage upon the wife's social situation and provides the judge with the opportunity to compel the husband

\section{0 al-Nīsā' 4/34.}

91 His interpretation of $t e^{\prime} d \bar{\imath} b$ means disciplining and training misbehaviour of the wife. His concept includes slightly beating the disobedient wife, but he does not approve to beat the wife that damages organs or parts of her body. See, Ibn Qudāma, Al-Käfì vol. 3, 92-94.

92 al-Nīsā' 4/128.

93 Al-Khiraqī, Matn al-Khiraq̄i, 111.

94 Al-Ṭusīi, A Concise, 373-375.

95 Al-Ṭūsī, A Concise, 357.

96 Al-Ṭūsī, Kitāb al-Khilāf, vol. 5, 112-114. 
to divorce the wife. ${ }^{97}$ In instances where the husband is absent for a particular period and the guardian does not volunteer to provide maintenance to the wife, she can, in indicating her unwillingness to await the return of the absent husband, bring the case to the judge for divorce approval. The judge should ask her to wait for four years from the date when she brought the case to him. If the husband fails to respond for four years, the following solution is initiated:

\footnotetext{
"If there is no guardian of the missing husband, the judge shall divorce the woman, and two just witnesses shall testify to the divorce, so that the divorce by the judge shall be treated as the divorce by the husband. The woman shall observe 'idda for four months and ten days. Thereafter, she may marry if she so desires." ${ }^{98}$
}

There are special types of divorces that have detailed prescriptions depending on the Qur'an or Sunna, and both Hanbalī and Ja'farī schools mainly follow similar paths concerning with these divorces. If there is irrevocable termination in the form of mutual imprecation among spouses ( $\left.l i{ }^{\prime} \bar{a} n\right)$, the judge, after taking the accusations of the respective parties into account, orders the dissolution of the marriage..$^{99}$ The judge adjusts later arrangements pertinent to the affiliation of the child, their inheritance or the waiting period. ${ }^{100}$ The essential condition of the $l i{ }^{\prime} \bar{a} n$ establishes that it is necessary to conduct the hearing in the presence of a judge or his representative relaying on the Qur'anic verse. ${ }^{101}$ The responsibility ascribed to the judge and his subsequent judgement places this genre under the category of tafri $q$ divorces and it can therefore be said to be a dissolution of the marriage rather than a repudiation. ${ }^{102}$ In the case of an oath of sexual abstinence from the wife ( $\left.\bar{l} l \bar{a}^{\prime}\right)$, the wife is entitled to bring the case before the judge after four months pass. ${ }^{103}$ The judge is then entitled to offer alternatives, whether in the form of repudiation or return. ${ }^{104}$ As the complication is resolved through the guidance of the judge, this type can also be referred to as tafri $q$. If the parties, during the judgement process, send their deputies for reconciliation, their decision is binding upon the couple - the exception is the termination of the contract as the representative is

97 Naqvi, Shia Divorce, 386.

98 Naqvi, Shia Divorce, 342,343,349.

99 Mehmet Akif Aydın, "Liān," Türkiye Diyanet Vakfi İslam Ansiklopedisi (Ankara: TDV Yayınları, 2003), vol. 27, 172; Al-Ṭūsī, A Concise, 367; Ibn Qudāma, Al-Kāfí, vol. 3, 180-181.

100 Al-Awwal, Al-Lum 'a, 190-192; Ibn Qudāma, Al-Kāfì, vol. 3, 188.

101 al-Nūr 24/6-9.

102 Al-Awwal, Al-Lum 'a, 191; Al-Thānī, Sharh al-Lum 'a, vol. 3, 34; Ibn Qudāma, Al-Kāfì, vol. 3, 181.

103 Hamdi Döndüren, "Īlā," Türkiye Diyanet Vakfi İslam Ansiklopedisi (Ankara: TDV Yayınları, 2000), vol. 22, 61-62; Ibn Qudāma, Al-Kāfì, vol. 3, 155-156; Al-Ṭūsì, A Concise, 372.

104 Al-Ṭūsī, Kitāb al-Khilāf, vol. 4, 510-511; Ibn Qudāma, Al-Kāfì, vol. 3, 162. 
required to demonstrate the authority of divorce in order to favour his claim. ${ }^{105}$ The permission of deputies for cancellation should be aligned with time limitations in order to provide their decision with enhanced legitimacy and validity.

\section{Conclusion}

Within the scope of Islamic law, the husband is entrusted with an authority in marital relations to such an extent that he is entitled to dissolve the marriage by pronouncing the divorce formula (talāq) through extra-judicial and unilateral means. The categorisation of the divorce formula, whether in explicit or implicit form, is identified in conformity with the interpretation of textual sources. Although the divorce occurs with an implicit declaration, it could be conducted upon equitable terms and in accordance with the shar ' $\bar{i}$ prescriptions. An explicit or implicit pronouncement of termination is considered to be a proper divorce and it becomes effective within the scope of the Hanbalī school. In diverging from the classical Hanbali approach, the refusal to permit the metaphorical usage of the divorce formula could be interpreted as a rejection and reluctance to sanction easy divorce in the Ja 'fari school. However, in the case of those who have specific disabilities, the classical Ja'farī sources also recognise various methods or metaphorical forms of annulment. The requirement of having at least two witnesses for the validity of talāq divorce in the Ja'fari school makes its procedure different from the practices in the Hanbalī school.

As for the khul' divorce, there should be a complete harmony of disposition and full agreement between the husband and wife upon the khul 'divorce in both schools. The immediate irrevocable divorce occurs when the husband utters a single pronouncement of the formula and in turn receives compensation from the wife. In accordance with both schools, it is considered to be disgraceful and unrecommendable for the husband to ask for an amount that exceeds the dower. Although there is no specified maximum amount of compensation for $k h u l$ 'divorce in the Hanbali school, the lower price of compensation is established as three dirhams. The dower limit that ranges from the lowest level up to fifty dinars is decided by the Ja'farī school in accordance with the specific societal context, including location and time. Once the marriage is terminated by the payment of a ransom, the marriage type is considered to fall within the category of irrevocable divorce. During the marriage, the parties might set conditions that relate to possible and undesired events. The absence or existence of particular conditions in a marriage contract provides both parties with the option to pursue an annulment on reasonable grounds. If the condition is stipulated in the marriage contract, the occurrence 105 Naqvi, Shia Divorce, 28. 
of the condition entitles both parties to apply to the termination of the marriage within the framework of talī $q$ or tafwì with the Ja'farī school, offers quite extensive opportunities to both parties for conditional divorces.

Classical Hanbalī and Ja'farī sources establish that the judge should approve divorce in instances where problems between the parties are obvious and where there is a clear danger that shar ' $\bar{l}$ limitations upon the continuation of the marriage will be exceeded. The participation of the judge into divorce procedure and his sanctioning power change the nature of divorce and turn it into tafrī $q$ or fask $h$ divorce. In both Hanbali and Ja'farī schools, it is agreed that the judge has right to terminate the marriage upon the request of the parties concerning defects or physical problems. The existence of a defect that is unknown at the time of marriage contract gives reasonable grounds for the annulment of marriage to the wife being entitled to maintenance and lodging in this circumstance. The shar ' $\bar{l}$ scope of disobedience refers to the violation of marital duties and terms by either the husband or wife. It provides divorce right to both spouses without renouncing their financial rights. The extent of disobedience which includes failing to obtain the husband's permission or similar acts brings out the connection between local values, social norms and interpretation of textual sources in accordance with the approaches of scholars affiliate to the Hanbalī and Ja 'farī schools. The undeniable connection between social values and implementation of religious rulings regarding marital issues has frequently been acknowledged by the classical scholars. This connection enables the schools to adjust the textual sources according to their respective environments and provides practicality to the theoretical regulations. The comparative analysis between Hanbalī and Ja'farī schools, therefore, reveals the similarity between the legal rulings of the two schools regarding divorce issues. Although there are detectable differences for the divorce practices between the regulations and rulings of the two schools, they mainly follow the similar rulings which are deduced from the foundational sources of the two schools. The jurisprudential methodologies of the schools that was shaped within their respective environments and the social, cultural and historical contexts in which the rulings regarding the divorce were formulated, are both regarded as the main elements that lead to these noticeable differences today.

Peer-review: Externally peer-reviewed.

Conflict of Interest: The authors have no conflict of interest to declare.

Grant Support: The authors declared that this study has received no grant support. 


\section{References}

Acar, H. İbrahim. "Talāk.” Türkiye Diyanet Vakfi İslam Ansiklopedisi. Vol. 30, 496-500. Ankara: TDV Yayınları, 2010.

—. "Tefrik.” Türkiye Diyanet Vakfi İslam Ansiklopedisi. Vol. 40, 277-279. Ankara: TDV Yayınları, 2021.

Al-Atawneh, Mumahhad. Wahhābì Islam Facing the Challenges of Modernity. Leiden, Boston: Brill, 2010.

Al-Awwal, al-Shahīd (Al-‘Āmilī, Muhammad ibn Jamāl al-Dīn Makkī). Al-Lum 'a al-Dimashqiyya. Qom: Dār al-Fiqr, 1994.

Al-Hiillī, Al-Hasan ibn Yūsuf Ibn al-Mutakhhār. Mukhtalaf al-Shī 'a fì Aḥkām al-Sharī 'a. Qom: I'timād, 2000.

Al-Khiraqī Abū al-Qāsim, 'Amr ibn al-Husayn. Matn al-Khiraqī 'alā Madhhab Abū 'Abdallāh Ahmad ibn Hanbal al-Shaybānī. Medina: Dār al-Șahāba li-Turāth, 1993.

Al-Kulaynī, Muhammad ibn Ya'qūb. Furū'al-Kāfì. Beirut: Manshūrāt al-Fajr, 2007.

Al-Manșūr, Șāliḥ ibn ‘Abd al-'Azīz. Usūl al-Fiqh wa Ibn Taymiyya. Egypt: Dar al-Nashr, 1985.

Al-Ṭabāțabā'̀̄, Muḥammad Ḥusayin. An Introduction to Shi'i Law: A bibliographical Study. London: Ithaca Press, 1984.

Al-Thānī, al-Shahīd (Al- 'Āmilī, Zayn al-Dīn 'Ali ibn Ahmad). Al-Raw ḍa al-Bahiyya Sharh al-Lum 'a al-Dimashqiyya. Qom: Al-Mu’esse al-Ismā‘iliyya, 1999.

Al-Turkī, ‘Abdullah bin ‘Abd al-Muhsīn. Usūl Madhhabī Imām Aḥmad. (Mu'assese al-Risāla, 1990.

Al-Ṭūs̄̄, Abū Ja'far Muhammad ibn al-Hasan ibn 'Ali. A Concise Description of Islamic Law and Legal Opinions. trans. A. Ezzati. London: Icas Press, 2008.

—. Kitāb al-Khilāf. Najaf: Al-Nashr al-Islāmīe 1995.

—. Al-Mabsūt fì Fiqh al-Imāmiyya. Beirut: Dār al-Kitāb al-Islāmī, 1992.

Ali, Kecia. "Marriage in Classical Islamic Jurisprudence: A Survey of Doctrines." In The Islamic Marriage Contract Case Studies in Islamic Family Law. Edited by Asifa Quraishi and Frank E. Vogel, 11-45. Massachusetts: Harvard University Press, 2008.

Anșārī, Murtaḍā. Al-Farā'id al-Ușūll. Qom: Bāqirī, 1998.

Atar, Fahrettin. "Muhālea." Türkiye Diyanet Vakfi İslam Ansiklopedisi. Vol. 39, 399-402. Ankara: TDV Yayınları, 2005.

Aydın, Mehmet Akif. "Liān." Türkiye Diyanet Vakfi İslam Ansiklopedisi. Vol. 27, 172-173. Ankara: TDV Yayınları, 2003.

Döndüren, Hamdi. "Īlā." Türkiye Diyanet Vakfi İslam Ansiklopedisi. Vol. 22, 61-62. Ankara: TDV Yayınları, 2000.

El-Alami, Dawoud and Doreen Hinchcliffe. Islamic Marriage and Divorce Laws of the Arab World. London: CIMEL, 1996.

Elgawhary, Tarek. Rewriting Islamic Law; The Opinions of the 'Ulamā' Towards Codification of Personal Status Law in Egypt. New Jersey: Gorgias Press, 2019.

English Translation of the Message of the Qur'an. Translated by Syed Vickar Ahamed. Illinois: Books of Signs Foundation, 2007.

Government of Iran. "The Civil Code of the Islamic Republic of Iran." National Legislative Body. 23 May 1928. Accessed 20 November, 2020. https://www.refworld.org/docid/49997adb27.html. 
-. "The Constitution of the Islamic Republic of Iran." National Legislative Body. 24 October 1979. Accessed 20 November, 2020. https:/www.refworld.org/cgi-bin/texis/vtx/ rwmain?page $=$ search\&docid $=3$ ae6b56710\&skip $=0 \&$ query $=$ constitution $\% 20 \&$ coi $=$ IRN .

Günay, Hac1 Mehmet. “Nüşūz.” Türkiye Diyanet Vakfi Islam Ansiklopedisi. Vol. 33, 303-304. Ankara: TDV Yayınları, 2007.

Ibn Mājah al-Qazwin̄̄, Muhammad ibn Yazeed. Sunan Ibn Mājah. Translated by Nasiruddin alKhattab. Riyadh: Darussalam, 2007.

Ibn Qayyim al-Jawziyya, Muhammad ibn Ab̄̄ Bakr ibn Ayyūb. Iqhāthat al-Lahfān fì Hukm Talāq al-Ghaḍā̄n. Jeddah: Majmu'u al-Fiqh al-Islāmī.

Ibn Qudāma al-Maqdisī, 'Abdullah ibn Aḥmad ibn Muhammad. Al-Kāfî fì Fiqh Ahmad Ibn Hanbal. Beirut: Dār al-Kutub al-'Ilmiyya, 1994.

Ibn Taymiyya, Ahmad Ibn 'Abd al-Halīm. Majmū' al-Fatāwā. Dār al-Wafā', 2005.

Kamali, Mohammad Hashim. Principles of Islamic Jurisprudence. Cambridge: St Edmundsbury Press, 1991.

Karataş, Mustafa. "Sābit b. Kays b. Semmās.” Türkiye Diyanet Vakfi İslam Ansiklopedisi. Vol. 35, 352-353. Ankara: TDV Yayınları, 2008.

Mir-Hosseini, Ziba. "The Delegated Right to Divorce in Iran and Morocco." In Talāq-i-Tafwid: The Muslim Woman's Contractual Access to Divorce. Edited by Lucy Carrol and Harsh Kapoor, 121-134. WLUML, 1996.

Naqvi, Syed Ali Raza. Shia Divorce Law. Lahore: The Ahl al-Bait, 2012.

Nasir, Jamal J. The Status of Women Under Islamic Law and Under Modern Islamic Legislation. London: Graham Trotman, 1990.

Nezhad, M. Zarra. "A Brief History of Money in Islam and Estimating the Value of Dirham and Dīnār.” International Association for Islamic Economics 8, no. 2 (2014): 51-65.

Șadr, Muhammad Bāqir al-. Al-Mu 'ālim al-Jadīda li-Ușūl. Tehran: Maktaba al-Najāḥ, 1975.

Spectorsky, Susan A. Chapters on Marriage and Divorce Responses of Ibn Hanbal and Ibn Rahwayh. Austin: University of Texas Press, 1993.

Vogel, Frank E. Islamic Law and the Legal System Studies of Saudi Arabia. Leiden, Boston, Köln: Brill, 2000.

Yakar, Emine Enise. "The Influential Role of the Practice of Iftā' in Saudi Politico-Legal Arena." Manchester Journal of Transnational Islamic Law and Practice 16, no. 1 (2020): 35-61.

Yakar, Sümeyra. "The Consideration of Bid 'a Concept according to Saudi and Iranian Scholars," Mazahib Jurnal Pemikiran Hukum Islam 19, no. 2 (2020): 219-247. https://doi.org/10.21093/mj.v19i2.2645.

—. "The Usage of Custom in the Contemporary Legal System of Saudi Arabia; Divorce on Trial." Kilis 7 Aralık Üniversitesi İlahiyat Fakültesi Dergisi 6, no. 11 (2019): 395-419. 